\title{
Islamic Banking: The Firewall Against The Global Financial Crisis
}

\author{
Rohana Othman, Accounting Research Institute, Universiti Teknologi MARA, Malaysia \\ Nooraslinda Abdul Aris, Accounting Research Institute, Universiti Teknologi MARA, Malaysia \\ Rafidah Mohd Azli, Accounting Research Institute, Universiti Teknologi MARA, Malaysia \\ Roshayani Arshad, Accounting Research Institute, Universiti Teknologi MARA, Malaysia
}

\begin{abstract}
The global financial crisis that devastated many of the world's financial systems in a manner never seen before exposed the glaring weakness in risk management and interest-driven policies. The crisis brought the collapse of several iconic financial institutions once perceived to be too strong to capitulate. The crisis engulfed one economy after another from corporations to eventually bring about the collapse of governments of countries reeling from the impact of the crisis. Asset values plummeted and the crisis clearly demonstrated the fragility of the western capitalist system and the free market economy. The Islamic economic and financial system is anchored on universal honorable values, ideals and morals - honesty, credibility, transparency, co-operation and solidarity. These fundamental values uphold stability, security and safety in any financial transactions. Of paramount consideration is that the Shari'ah prohibits any economic and financial transactions that involve usury, lying, gambling, cheating, unsubstantiated risk or uncertainty (gharar), monopoly, exploitation, greed, unfairness and taking other people's money unjustly. Another key aspect to the philosophy behind the Islamic financial system is money issued must be fully asset backed. It is impermissible to allow money to be traded for money except at par. Islam is not just the prohibition of riba and zakah (alms); it is a comprehensive system to fulfill society's basic necessities (food, clothing and shelter). History has demonstrated that Islam has the capacity to deliver and has succeeded in providing a viable economic system.
\end{abstract}

Keywords: Islamic Economy; Islamic Banking; Financial Crisis; Shari’ah; Gharar; Zakah; Riba

\section{INTRODUCTION}

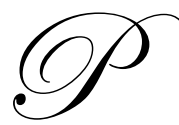

ast crises derive opportunities to learn. In an odd twist of fate, the onset of the subprime crisis in 2007, which within less than a year escalated into a global financial crisis on a scale never before seen since the Great Depression in 1930, ironically occurred around the tenth anniversary of the Asian Financial Crisis 1997. Terms that were synonymous with the Asian debacle, such as currency pegs, excessive corporate borrowings, and foreign debts, have morphed into scintillating buzzwords - securitization, subprime mortgages, and collateralized debt obligations (CDOs) - among many. Both episodes were triggered under similar circumstances; investors panic in the face of uncertainty over the security and valuation of assets. Each featured a run on cash reserves and rising insolvency in the banking system.

The global financial crisis that ensued was seen by many as the harbinger of a worldwide economic recession. Indeed, the aftermath left behind a graveyard of corporate carcasses at the epicenter of the crisis in the United States, from Circuit City to Linens n' Things to Lehman Brothers. Thousands of smaller businesses closed. Millions were laid off with only the shirts on their back and a bleak future ahead. AIG, Fannie Mae and Freddie Mac are staggering along as wards of the state. General Motors, Chrysler, Citigroup and several other name-brand firms would probably be toast too if not for bailouts and forgiving consumers.

On the international scene, model developed nations also began to crumble under the intense pressure of a crisis that triggered a run on their financial institutions, which in turn began to run afoul of the liquidity equilibrium. 
This was clearly demonstrated by Iceland, where the government of the day collapsed and was replaced by an equally shaky new administration that has yet to succeed in reviving the nation's teetering economy. More recently, the Grecian economy buckled under the weight of foreign debts and was forced to succumb to demands by fellow European Union members and the International Monetary Fund to adopt more prudent financial policies as a condition for financial assistance, a situation akin to modern colonialism. Only time will tell if the remedies could bring about the desired results.

In demonstrating the inter-linkages of the global financial system and echoing the devastating impact of the Great Depression, the crisis was not only restricted to North America or Europe. The rest of the world was also impacted, albeit in varying degrees of devastation. The third world and developing nations were not spared. Indonesia, Singapore, Malaysia, Pakistan, Bangladesh, South America and the Middle East, which had in the past decade readily embraced the idea of free markets and participated in capitalistic financial markets, had speculated large sums of wealth in the state of the economy and future revenue flows (Hassan, 2008). Reeling from the losses in value of their wealth, some of these nations are only now beginning to pick up the pieces of their battered financial system.

The Global Financial Crisis potentially brought to a halt more than a decade of increasing prosperity and employment for western economies and wiped out an estimated staggering USD1 trillion off the value of the world economy (Boeri and Luigi, 2008).

A crisis on the scale, such as the global financial crisis, will undoubtedly be the subject of many studies, particularly in analyzing the causes and effects. In general, many economics experts and commentators concur that the cause of the crisis was the lack of proper regulation, legislation and transparency (Cecchetti, 2008b; Adrian, and Shin, 2008; Goodhart, 2008).

\section{The Global Financial Crisis: What It Really Means}

The United States, the epicenter of the crisis, suffered two main effects. Firstly, the willingness and readiness of banks to lend money dwindled and the effect was to inflate the price of borrowing. Worldwide, the value of bonds issued against mortgages tumbled from USD1.9 billion to USD500 million in 2008. Secondly, some financial institutions were either wiped out or forced to go begging for bailouts to stay afloat and these financial institutions formed the backbone of the private finance initiative (PFI) industry, particularly the monocline insurers that insure the bonds issued to raise money for PFI projects (Cecchetti, 2008a). To be fair, these institutions self imploded by being guilty of buying devious mortgage-backed securities which led to the loss of the credit ratings they could lend to bond issuers. Defaults in the US market from risky mortgages have caused major global credit turmoil, as massive US losses led to a squeeze on international credit markets and a subsequent fall in global equity market.

This crisis, and other similar crises dating back to the Great Depression in 1930, highlighted the fragility of the western capitalist system and the free market economy, and demands for a more viable alternative is certain to arise from the fallout of the subprime crash and the wider economic crisis (Hassan, 2008).

The recurring theme among Islamic economists (Siddiqi, 2009; Chapra, 2009; Bagsiraj, 2009) points the finger at the interest-based financial system for the global economic crisis. In fact, every crisis since the Great Depression can be traced to flaws in the interest-based system. Concurrently, the situation is compounded by huge budgetary imbalances, excessive monetary expansion, and large balance of payment deficits, insufficient foreign aid, and inadequate international cooperation.

Islamic economics principles are, on the other hand, founded on justice, equity and welfare. Guided by these principles, Islamic economics aims to establish an all encompassing solace minus the plague of unemployment, while the economy is maintained at an optimum growth rate (Hassan, 2008). The situation trickles down to equitable distribution of wealth and income and socio-economic justice. In Islamic economics, money is a reliable unit of account and a stable store of value. Money becomes a trustworthy medium of exchange and is free from unstable fluctuations in value. 
Going further, an Islamic banking system will serve to circumvent any credit crunch or, on a larger scale, a global financial crisis because Islamic financial institutions operate on the principle of partnership between client and the banks. It is imperative that Islamic banking and finance be underlined with social commitment.

\section{Financial Economy Versus Real Economy}

In a nutshell, real economy comprises of housing and real estate, land and property, factories, cars and goods, manufacturing industries, primary production, etc. Tangible goods are produced, traded, leased and sold. At every stage of the economic process, there exists employment with people to make and move the physical goods.

The financial economy, however, consists of tradable paper that fluctuates based on the value people give them, often speculatively, with no real asset represented. In the financial economy, participants gamble on the outcomes of the real world by betting on the performance of businesses and on their profits. The analogy is the financial sector exists in parallel alongside the real economy but without any real production.

In the previous three decades, western economies underwent a major shift from primary productivity to services. It is estimated that the service sector now represents over 80 percent of the US economy. The financial sector makes up the largest component of the service industry (Hassan, 2008).

In terms of value, the financial economy dwarfs the real economy. The global bond market is estimated to be worth USD45 trillion, while the world's stock market collectively stands at approximately USD51 trillion. Total derivatives are valued at about USD480 trillion, worth more than 30 times the US economy and 12 times the size of the entire world's economy (Hassan, 2008).

With such colossal numbers, miniscule changes in rates and interests can lead speculators to reap huge short-term profits. The concept of receiving returns from dividends thus becomes antiquated. The level of speculation then becomes gigantic and supersedes any effort to impose controls. It was under this illusion that many banks and financial institutions were driven by greed to buy hundreds of thousands of home loans given to Americans who were actually incapable of making their payments. This triggered the subprime crisis and credit crunch. The Institute of International Finance estimated that the financial institutions involved had to write down USD476 billion of their assets since huge chunks of it were technically worthless.

With the advent of the financial economy, financial institutions embarked on a secondary financial market that thrived on the creation of complex financial products and debt instruments that were securitized, collateralized and traded between financial institutions, like a real commodity. Securitization inflated the interest rates which enabled many institutions to profit from the trading of debt instruments. Executives were blinded by the astronomic commissions they stand to make and compromised on control and prudence. Such huge amounts of money flooding the market, none based on real assets, created a financial bubble accompanied by rising inflation. The price of commodities, like petroleum and food, shot sky high which caused the poorer nations of the world to cringe in fear. When the bubble suddenly burst, the world experienced turmoil and financial institutions suffered from lack of liquidity since their "money" were mere numbers and not real.

The most significant factor to destabilize modern markets is the activity of money creation by the banking system. For generations, central banks and commercial banks have been responsible for a succession of speculative bubbles by creating money out of nothing and proceeding to lend it into circulation (al-Haddad and el-Diwany, 2008). Newly created money increases the amount of money in circulation and inflates the prices of assets, such as property and shares. On the other hand, a reduction in the rate of money creation reduces consumers' buying power and prices fall. As such, money creation becomes a powerful tool in economics or politics. It is becoming the norm that this tool is abused.

The credit crunch occurred as financial institutions began imposing more stringent conditions on loan applications to protect their positions. Governments the world over were forced to pump in billions of dollars to revive their ailing economy. 
In the aftermath, economists and political makers from both sides of the political divide and economics schools of thought stressed on the need for more stringent regulations and increased transparency. Only a few acknowledged greed and speculation. The very "sins" that the Islamic financial system had addressed were equally, if not more, guilty.

\section{Islamic Banking, The Solution To The Financial Crisis}

A crisis, such as the subprime mortgage meltdown, would technically be unthinkable in the Islamic capital markets sector because it would be against the Shari'ah principles to sell a debt against a debt. The global financial crisis, sparked by the US subprime mortgage meltdown, would not have occurred if Islamic principles were applied in international financial markets (al-Haddad and el-Diwany, 2008).

Calls on the need for a new approach to banking and finance, considering how fragile and the high propensity for abuse inherent in the conventional banking systems, is becoming more frequent. Despite being promoted as a possible alternative, the Islamic financial system in practice is still viewed as being modeled after its interest-based counterpart. The Islamic financial industry has only to introspect and admit the industry has failed to properly implement the ideals upon which it begun 30 years ago.

Islam shares commonalities with the capitalist and socialist financial model on certain elements, particularly concerning dedication to work, productivity and maximizing income. However, Islam also expounds believers of an everlasting life upon judgment of the worldly conduct. Hence, greed and excessive attachment to money is discouraged.

The Islamic economic and financial system is anchored on universal honorable values, ideals and morals, like honesty, credibility, transparency, co-operation and solidarity. These fundamental values uphold stability, security and safety in any financial transactions. Of paramount consideration is the Shari'ah which prohibits any economic and financial transactions that involve usury, lying, gambling, cheating, unsubstantiated risk or uncertainty (gharar), monopoly, exploitation, greed, unfairness and taking other people's money unjustly. Another key aspect to the philosophy behind the Islamic financial system is money issued must be fully asset backed; it is impermissible to allow money to be traded for money, except at par (Hassan, 2008).

The global financial crises would not arise if the financial system had been implemented properly in compliance with the guidelines and limits laid out in the Shari'ah. The issue of risk-sharing can demonstrate this point clearly. When commercial banks are required to share not only in the profits but also the losses of their clients, be it in business investments or mortgages, they would practice greater prudence in deciding which deals to finance. Their financial returns hinge on the performance of the projects.

Islamic banking would disallow common practice of fractional reserve banking where banks lend out more money than they have in deposits. Then a small amount of equity is sufficient to be used as collateral for large borrowings. When money is created virtually out of thin air, a financial bubble is created which adds to the volatility of the financial system.

Conversely, Islamic banks act as venture capital firms collecting wealth from the public and investing it. The profit generated is then distributed equitably among depositors. Islamic banks are technically investment partners providing capital to do business, becoming part owners of the business. The bank will only recoup their original capital by selling their share of the business at the prevailing market price. Being real partners, Islamic banks would not object to owning real assets and are ready to share in the consequential risk. Clients, too, would be relieved with the fact that they will cease to be burdened by debts or cringe in fear of seizure of assets via repossession.

Islamic bonds, or sukuks too, carrying unique structure features, cannot fall foul of a crisis, such as with the subprime mortgage. Subprime mortgages are backed by dubiously rated collateralized debt packages which subsequently precipitate a global credit crunch. 
Islamic finance principles stipulate that deals must be based on tangible assets and require tight controls on debt levels - features that analysts say offer some protection to investors and ensure corporate accountability.

\section{Barriers to Islamic Banking}

Islamic banking, being the "youngest kid on the block" in the banking and finance industry, faces myriad challenges to be accepted as a viable, if not preferred, alternative to conventional banking. Firstly, the bulk of an economy is driven and manipulated by interest or usury. The task to change the interest driven mindset will undoubtedly be a daunting one. The central bank's role as regulator and fiscal policy custodian too, is structured for the conventional commercial banks.

Central banks also act as lender of a last resort to salvage ailing financial institutions. There will then have to be put in place a parallel mechanism, in compliance to the Shari'ah, to provide the patronage currently afforded to conventional banks. However, the incompatibility in operational procedures may necessitate a separate control and support system. Islamic banks also run the risk of being ensnared into the systemic problems currently plaguing conventional banks; for example, proper regulation, risk-management and money creation via lending, which exposes Islamic banks to the same cycle of inflation or boom-bust.

The onus is on Islamic scholars to delve into the Shari'ah Islamic business practices and agree upon a set of regulations and procedures that will enable the Islamic banking system to operate, at least at par with its conventional counterpart. One of the core issues that needs redress is risk-sharing. Risk-sharing in Islamic finance should do away with conflicts of interest, making the economy more stable.

Another cornerstone of conventional banking that Islamic banking would be able to curtail is the creation of money. The practice is widespread for conventional banks to create money out of nothing by lending out their deposits and putting it back into circulation. The newly created money is then spent to acquire assets, like property and shares, effectively hiking up the prices due to increased demand. The application of the law of "trust" and the prohibition of interest (riba) would curtail the creation of money. Thus, issuing "covenants to repay" in excess of available cash reserves would not be possible.

\section{CONCLUSIONS}

Just as crises that occurred in the past, the global financial crisis displayed similar factors inherent to capitalism and its weaknesses in risk management and interest-driven policies. Capitalism and the free-market economy are open to abuse and are fragile. The aftershock from the crisis leads to a growing demand for viable alternatives that are more reassuring and trustworthy.

In the midst of such turmoil, Islamic banking and finance turned out unscathed and is witnessing phenomenal growth. The global value of Islamic finance is approaching USD1 trillion. The Asian Development Bank estimates that the annual growth of the Islamic banking and finance sector exceeds 15 percent (Hassan, 2008).

The aftermath of the financial crisis saw massive write-downs of losses, coupled by widespread sacking of executives and worldwide recession and economic catastrophes. Lending becomes more stringent as greater prudence is employed in addition to numerous financial institutions experiencing liquidity issues. Inflation too reared its ugly face with global hikes in the price of oil and consumer product.

A financial system that is driven by true Islamic principles will succeed to prevent a financial crisis. The practice of paying and receiving interests, together with the artificial creation of money via fractional reserve banking, is prohibited. Fractional reserve makes it possible for very little equity to be used as collateral in making large borrowings. Thus, the reintroduction of money to flood the economic system is halted and inflation and financial bubbles are not created.

By Islamic financial institutions acting more in line as venture capitalists, risk management is well executed, prudence is fully observed, honesty, transparency and accountability is highly regarded, and proceeds are 
equally shared among all partners involved. Clearly, with Islamic banking, the outcome is a win-win proposition. Society ceases to be victimized by unscrupulous, greedy and unethical conventional financial establishment via complex financial instruments that promises high yields but are actually tome bombs waiting to dissipate in value.

The moment is right for Islamic banking and finance to come out of its cocoon and offer equitable remedies to a rapidly receptive global market. There exists an unprecedented opportunity to open up details of the Islamic economic system as well as the solutions that can be proffered by Islamic finance for some of the problems in the current financial crisis.

Islam is not just the prohibition of usury (riba) and zakah (mandatory alms); it is a comprehensive system to fulfill society's basic necessities (food, clothing and shelter). The focus is always on people and their needs. Market players, economists, analysts, financial experts and the public need to be made aware of the universal Islamic values that expound a complete way of life, socially, in trade and finance, consumerism, in this world and onwards to the hereafter. The key association to recompense in the hereafter is motivation to do right in this life, thus ensuring solidarity, harmony, and the general good for mankind. History has demonstrated that Islam has the capacity to deliver and has succeeded in providing a viable economic system.

\section{REFERENCES}

1. Adrian, Tobias and Shin, Hyun Song (2008). "Liquidity, Monetary Policy, and Financial Cycles." Federal Reserve Bank of New York, Current Issues in Economics and Finance, January/February 2008, 14(1), p. 2.

2. Al-Haddad, H. and Tarek el-Diwany (2008). “Boom, Bust, Crunch: Is There an Islamic Solution?” (An Internet article downloaded from http://www.islamic-finance.com/item153_f.htm - date accessed: 28 May 2010).

3. Bagsiraj, M.I. (2009), "Financial and Economic Crisis An Alternative Indian Approach", Radiance Viewsweekly, Vol. XLVI No. 38, (2009-01-04 http://wwww.radianceweekly.com/137/3039/GLOBALMELTDOWN-Its-Viable-Alternative/2008-12-14/Cover-Story/Story-Detail/Current-Financial-Crisis-andIslamic-Economics.html - - date accessed: 28 May 2010).

4. Boeri, T. and G. Luigi (2008). "The Sub-prime Crisis: Greenspan's Legacy, in Andrew Felton and Carmen Reinhart, eds., retrieved from The First Global Financial Crisis of the $21^{\text {st }}$ Century, (www.voxeu.org/index.php?q=node/1352 - date accessed: 28 May 2010).

5. Chapra, M.U. (2009), “Global Islamic Financial Crisis, Can Islamic Finance Help?” New Horizon, JanuaryMarch, 2009, Issue No. 170, (http://www.newhorizon islamicbanking.com/index.cfm?section=archive \&action=view\&id=81 - date accessed: 28 May 2010).

6. Cecchetti, Stephen G (2008a). "Sub-prime Series: Part 4: Does Well-Designed Monetary Policy Encourage Risk-Taking?" in Andrew Felton and Carmen Reinhart, eds., The First Global Financial Crisis of the $21^{\text {st }}$ Century; www.voxeu.org/index.php?q=node/758.- date accessed: 28 May 2010).

7. Cecchetti, Stephen G (2008b). "Federal Reserve Policy Responses to the Crisis of 2007-8: A Summary," in Andrew Felton and Carmen Reinhart, eds., (The First Global Crisis of the $21^{\text {st }}$ Century, 2008c: www.voxeu.org/index.php?q=node/1048- date accessed: 28 May 2010).

8. Chapra, M.U. (2009), "Global Islamic Financial Crisis, Can Islamic Finance Help?” New Horizon, JanuaryMarch, 2009, Issue No. 170, http://www.newhorizon-islamicbanking.com/index.cfm?section=archive \&action=view\&id=81. (Date accessed: 28 May 2010).

9. Goodhart, Charles A.E (2008). "The Background to the 2007 Financial Crisis." International Economics and Economic Policy, 4(4), pp. 331-46.

10. Hassan, A. (2008). "The Global Financial Crisis and Islamic Banking." (Retrieved from http://www.islamic-foundation.org.uk/IslamicEconomicPDF/Hassan-financialcrisis.if.pdf.- date accessed 5 June 2010).

11. Siddiqi, M.N. (2009), "Current Financial Crisis and Islamic Economics," Radiance Viewsweekly, Vol. XLVI No. 38, 2009-01-04 http://www.radianceweekly.com/137/3039/GLOBAL-MELTDOWN-Its-ViableAlternative/2008-12-14/Cover-Story/Story-Detail/Current-Financial-Crisis-and-Islamic-Economics.htmldate accessed: 5 June 2010). 